University of Nebraska - Lincoln

DigitalCommons@University of Nebraska - Lincoln

1992

\title{
A Reconnaissance Study of Herbicides and Their Metabolites in Surface Water of the Midwestern United States Using Immunoassay and Gas Chromatography/Mass Spectrometry
}

\author{
E. Michael Thurman \\ US. Geological Survey \\ Donald A. Goolsby \\ US. Geological Survey \\ Michael Meyer \\ US. Geological Survey, mmeyer@usgs.gov \\ Margaret Mills \\ US. Geological Survey \\ Michael L. Pomes \\ US. Geological Survey \\ See next page for additional authors \\ Follow this and additional works at: https://digitalcommons.unl.edu/usgsstaffpub \\ Part of the Earth Sciences Commons
}

Thurman, E. Michael; Goolsby, Donald A.; Meyer, Michael; Mills, Margaret; Pomes, Michael L.; and Kolpin, Dana W., "A Reconnaissance Study of Herbicides and Their Metabolites in Surface Water of the Midwestern United States Using Immunoassay and Gas Chromatography/Mass Spectrometry" (1992). USGS Staff -- Published Research. 54.

https://digitalcommons.unl.edu/usgsstaffpub/54

This Article is brought to you for free and open access by the US Geological Survey at DigitalCommons@University of Nebraska - Lincoln. It has been accepted for inclusion in USGS Staff -- Published Research by an authorized administrator of DigitalCommons@University of Nebraska - Lincoln. 


\section{Authors}

E. Michael Thurman, Donald A. Goolsby, Michael Meyer, Margaret Mills, Michael L. Pomes, and Dana W. Kolpin 


\section{A Reconnaissance Study of Herbicides and Their Metabolites in Surface Water of the Midwestern United States Using Immunoassay and Gas Chromatography/Mass Spectrometry}

\section{E. Michael Thurman*}

U.S. Geological Survey, 4821 Quall Crest Place, Lawrence, Kansas 66049

Donald A. Goolsby

U.S. Geological Survey, Denver Federal Center, Building 25, Lakewood, Colorado 80225

Mlchael T. Meyer, Margaret S. Mills, and Mlchael L. Pomes

U.S. Geological Survey, 4821 Quail Crest Place, Lawrence, Kansas 66049

\section{Dana W. Kolpin}

U.S. Geological Survey, 400 South Clinton Street, Room 269, Iowa Clty, Iowa 52244

\begin{abstract}
Preemergent herbicides and their metabolites, particularly atrazine, deethylatrazine, and metolachlor, persisted from 1989 to 1990 in the majority of rivers and streams in the midwestern United States. In spring, after the application of herbicides, the concentrations of atrazine, alachlor, and simazine were frequently 3-10 times greater than the U.S. Environmental Protection Agency maximum contaminant level (MCL). The concentration of herbicides exceeded the MCLs both singly and in combination. Two major degradation products of atrazine (deisopropylatrazine and deethylatrazine) also were found in many of the streams. The order of persistence of the herbicides and their metabolites in surface water was atrazine $>$ deethylatrazine $>$ metolachlor $>$ alachlor $>$ deisopropylatrazine $>$ cyanazine. Storm runoff collected at several sites exceeded the MCL multiple times during the summer months as a function of stream discharge, with increased concentrations during times of increased streamflow. It is proposed that metabolites of atrazine may be used as indicators of surface-water movement into adjacent alluvial aquifers.
\end{abstract}

\section{Introduction}

Agricultural practices may cause widespread degradation of water quality in the midwestern United States $(1,2)$. Approximately three-fourths of all preemergent herbicides used in the United States are applied to row crops in a 12-state area, which is a major part of the "Corn and Soybean Belt" (3). Because many herbicides are partially water soluble, they may leach into groundwater and surface water (4), as well as be transported aerially and occur in precipitation $(5,6)$. Monitoring studies in the Midwest have shown widespread detection of herbicides in groundwater (7) and in surface water (8-10). Runoff from fields immediately after herbicide application results in substantial increases in herbicide concentrations in streams, which are reflected in increased concentrations in large rivers, such as the Mississippi (11). Furthermore, conventional water-treatment practices do not remove these soluble herbicides $(12,13)$, which then affect drinking-water quality. Herbicides also may have deleterious effects on aquatic vegetation (14-17).

In spite of these documented problems, the use of herbicides has become a standard practice for profitable row-crop farming in the United States, and elimination of herbicide use could create economic hardship for many farmers (18). Thus, it is important to understand the effects of herbicides on water quality. By water quality we mean the value of water as a resource for human and animal consumption, the ecological value of water, and the aesthetics of clean water (19). More data are needed to understand how herbicides affect water quality on a regional scale and throughout the hydrologic cycle. New analytical methods, such as immunoassay (20-22), enable analyses to be accomplished quickly and inexpensively. Furthermore, the results of these analyses may be mapped to understand herbicide distribution and transport. Geographic information systems (GIS) are new computer tools that make this mapping feasible. We combine these new analytical methods and mapping tools in a study of herbicide distribution and transport in the midwestern United States.

Our objective was to examine the effect of herbicides on regional surface-water quality, a scale at which little documentation exists (8). More specific objectives were to (1) test immunoassay with confirmation by gas chromatography/mass spectrometry (GC/MS) as an analytical tool for studying herbicide transport in the "Corn Belt", (2) compare herbicide concentrations in streams and rivers at a regional scale to Federal drinking-water standards, (3) examine the annual persistence of herbicides and their metabolites in surface water, and (4) assess whether metabolites of atrazine may be used as indicators of surface-water and groundwater interaction.

\section{Sampling and Study Area}

Water samples were collected at 149 reconnaissance sites in 122 hydrologic basins in a 10-state area (Figure 1A), which is a major part of the Corn and Soybean Belt. The states included Illinois, Indiana, Iowa, Kansas, Minnesota, Missouri, Nebraska, Ohio, South Dakota, and Wisconsin. A stratified random-sampling procedure ensured adequate geographic distribution. The number of sites per state was proportional to corn and soybean production, and sites were chosen randomly by county. Water samples were collected during March and April (preplanting), May and June (postplanting), and October and November (harvest) of 1989 at U.S. Geological Survey streamflow-gaging stations. Fifty sites were resampled with a stratified random procedure for both pre- and postapplication in 1990 to verify the 1989 results. Drainage areas of the selected basins range from 260 to more than $160000 \mathrm{~km}^{2}$, and collectively the basing drain more than $500000 \mathrm{~km}^{2}$ of the Midwest (Figure 1A).

All water samples were collected by depth-integrating techniques at three to five locations across each stream. The samples were collected and composited in large glass 


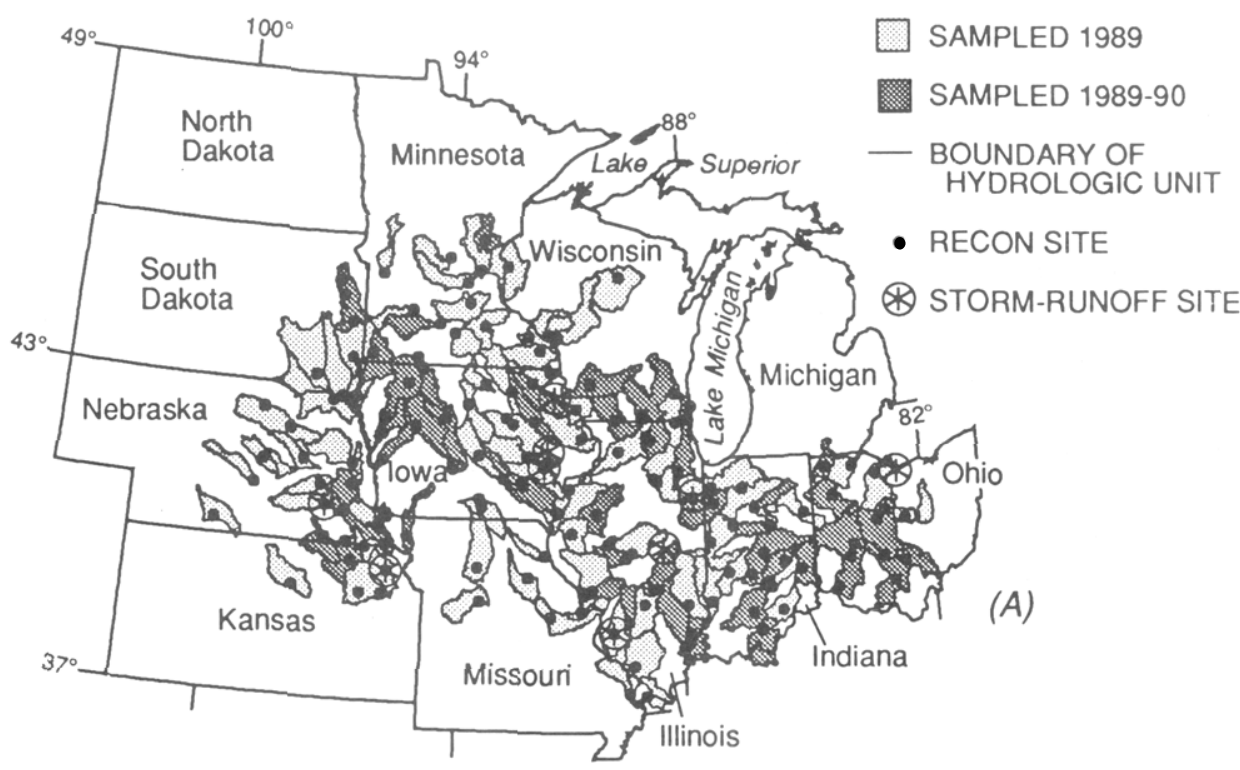

100200300 KILOMETERS

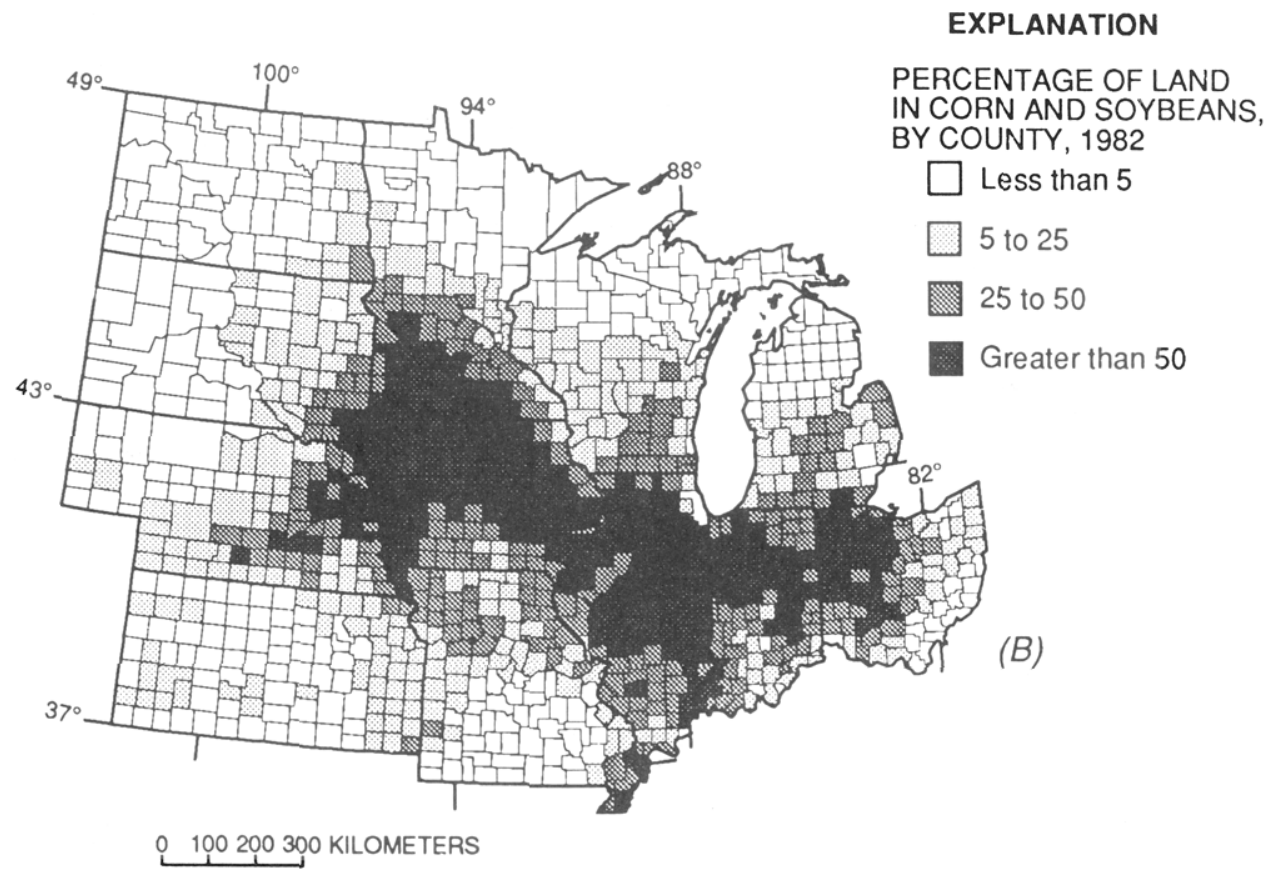

Flgure 1. (A, top) Map of the upper midwestern United States (the Corn Belt) showing location of study area, hydrologic basins, and basin sttes sampled in 1989 and 1990. (B, bottom) Percentage of land in the midwestern United States in corn (Zea mays L.) or soybeans (Glycine max L.); data from Gianessi and Puffer (3).

containers and filtered through glass-fiber filters $(1-\mu \mathrm{m}$ pore diameter) into baked glass bottles for shipment to the laboratory. Automatic samplers on nine streams in Illinois, Iowa, Kansas, Nebraska, and Ohio assessed the temporal distribution of herbicides during storm runoff in the spring and summer of 1990 . The drainage areas sampled ranged from 200 to $5000 \mathrm{~km}^{2}$. Samples were collected several times per week during base-flow periods and every few hours during storm-runoff events. All samples were analyzed for specific conductance, $\mathrm{pH}$, nitrate plus nitrite, and triazine herbicides by enzyme-linked immunosorbent assay (ELISA). Twenty-five percent of the samples were selected during both low and high flow for analysis by GC/MS.

A GIS software program called ARC-INFO was used to display spatial trends for land-use and water-quality in- formation on a Sun 3/20 workstation. The land-use data contain countywide estimates of crop and pesticide information for the year 1982 (3). Figure 2 was generated by determining triazine concentration with immunoassay $(21,22)$ at one or more sites within the 122 hydrologic basins in the study area. A median concentration per hydrologic basin was calculated for each collection period to more easily identify spatial trends in the data. These median concentrations were assumed to represent the entire basin.

\section{Experimental Section}

Materials. Methanol (Burdick and Jackson, Muskegon, MI), ethyl acetate, and isooctane (Fisher Scientific, Springfield, NJ) were pesticide-grade solvents. Deionized 

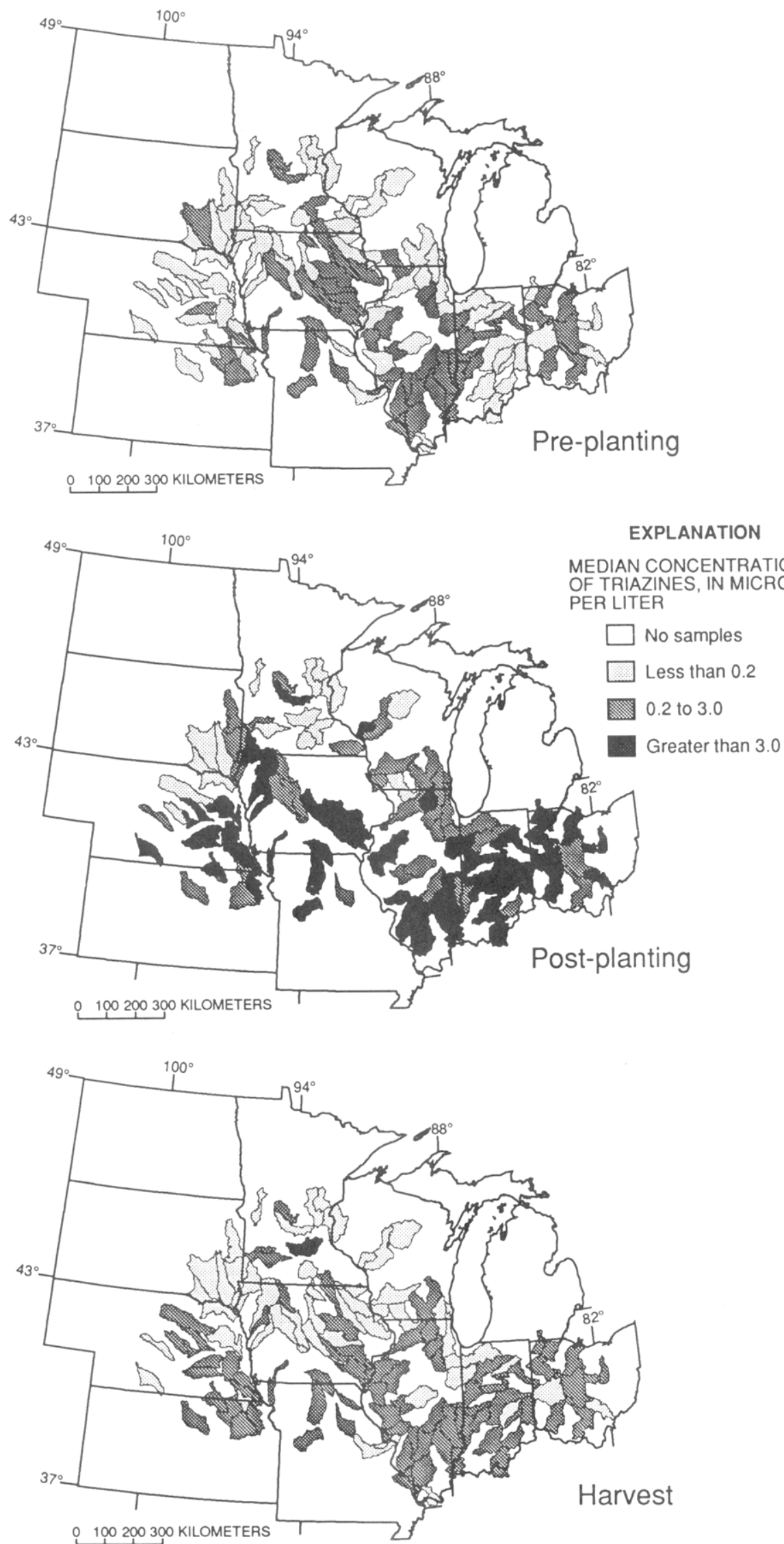

Flgure 2. Seasonal distribution of triazine herbicides in streams and rivers of the midwestern United States using computer-based geographic information system. Analyses were made by ELISA.

water was charcoal-filtered and glass-distilled prior to use. Ametryn, atrazine, prometon, prometryn, propazine, simazine, and terbutryn were obtained from Supelco (Bellefonte, PA); alachlor, cyanazine, metolachlor, metribuzin, and terbuthylazine standards were obtained from the United States Environmental Protection Agency (U.S. EPA) pesticide chemical repository (Research Triangle Park, NC); the triazine metabolites, deethylatrazine and 
deisopropylatrazine, were obtained from Ciba Geigy (Greensboro, NC). The $\mathrm{C}_{18}$ cartridges (Sep-Pak from Waters, Milford, MA) contained $360 \mathrm{mg}$ of $40-\mu \mathrm{m} \mathrm{C}_{18^{-}}$ bonded silica. Standard solutions were prepared in methanol, and phenanthrene- $d_{10}$ (EPA, Cincinnati, $\mathrm{OH}$ ) was used as an internal GC/MS quantitative standard.

Immunoassay Procedure. Res-I-Mune kits (ImmunoSystems Inc., Scarborough, ME) were used for the immunoassay analysis of water samples in the regional survey. The kit used polyclonal antibodies coated to the walls of a polystyrene test tube and an enzyme conjugate that was prepared by covalently binding atrazine to horseradish peroxidase using a modified carbodiimide technique (20). The immunoassay procedure was described previously by Thurman and others (21). Briefly, $160 \mu \mathrm{L}$ of sample was added to an antibody-coated tube with $160 \mu \mathrm{L}$ of enzyme conjugate, and $160 \mu \mathrm{L}$ of substrate was added followed by $160 \mu \mathrm{L}$ of chromogen, sequentially. After $2 \mathrm{~min}$, color was fixed with $40 \mu \mathrm{L}$ of "stop" solution ( $2.5 \mathrm{~N}$ sulfuric acid). Samples and standards were analyzed by measuring the percent inhibition, which is the difference in optical density at $450 \mathrm{~nm}$ between the negative control and the sample divided by the optical density of the negative control times 100.

Res-I-Qaunt kits (ImmunoSystems Inc.) were used for the storm-runoff samples. These kits consist of 96-well microtiter plates and reagents, which are more easily used and less expensive for large sample sets. Each of the wells on the polystyrene microtiter plate is coated with polyclonal antibodies (identical to Res-I-Mune kits). Samples were analyzed in duplicate. An $80-\mu \mathrm{L}$ aliquot of sample was used with $80 \mu \mathrm{L}$ of enzyme conjugate. Each plate was covered with Parafilm and allowed to incubate for $1 \mathrm{~h}$ at room temperature while being rotated at $180 \mathrm{rpm}$ on a orbital shaker. Upon completion the plate was flushed completely, rinsed five times with deionized water, and then tapped dry. Next, $160 \mu \mathrm{L}$ of substrate and chromogen was transferred into each well using a 12-channel pipet. Again, the plate was covered with Parafilm and allowed to incubate for $30 \mathrm{~min}$ at room temperature while rotating on an orbital shaker at $180 \mathrm{rpm}$. During this step, the action of the substrate and chromogen on the enzyme conjugate produced a blue color, which was inversely proportional to the analyte concentration. This reaction was halted with the addition of $40 \mu \mathrm{L}$ of sulfuric acid $(2.5$ $\mathrm{N})$, which changed the color from blue to yellow. Absorbances were read on a vMax spectrometer (Molecular Devices, Palo Alto, CA).

GC/MS Analysis. A Waters Millilab workstation (Milford, MA) was used for solid-phase extraction of the analytes. $C_{18}$ Sep-Pak cartridges were preconditioned sequentially with $2 \mathrm{~mL}$ each of methanol, ethyl acetate, methanol, and distilled water. Each 123-mL water sample was spiked with a surrogate standard, terbutylazine (2.4 $\mathrm{ng} / \mu \mathrm{L}, 100 \mu \mathrm{L})$, and pumped through the cartridge at $\mathrm{a}$ rate of $20 \mathrm{~mL} / \mathrm{min}$ by the robotic probe. Analytes were eluted with ethyl acetate and spiked robotically with phenanthrene- $d_{10}$. The ethyl acetate layer was transferred by probe to a clean test tube. Finally, the extract was evaporated automatically by a Turbovap (Zymark, Palo Alto, CA) at $45^{\circ} \mathrm{C}$ under a nitrogen stream to $100 \mu \mathrm{L}$. The robotic probe was washed between samples by immersing in $4 \mathrm{~mL}$ of ethyl acetate and bubbling air through the probe to ensure thorough removal of any herbicide or spike residues adhering to the outside of the probe.

Automated GC/MS analyses of the eluates were performed on a Hewlett-Packard Model 5890 GC (Palo Alto, $\mathrm{CA}$ ) and a $5970 \mathrm{~A}$ mass selective detector (MSD). Oper-

\begin{tabular}{|c|c|c|c|}
\hline compound & $\begin{array}{c}\text { concn for } \\
50 \% \\
\text { inhibition } \\
(\mu \mathrm{g} / \mathrm{L})\end{array}$ & compound & $\begin{array}{c}\text { concn for } \\
50 \% \\
\text { inhibition } \\
(\mu \mathrm{g} / \mathrm{L})\end{array}$ \\
\hline $\begin{array}{l}\text { atrazine } \\
\text { ametryn } \\
\text { prometryn } \\
\text { propazine } \\
\text { prometon } \\
\text { simazine }\end{array}$ & $\begin{array}{l}0.4 \\
0.45 \\
0.5 \\
0.5 \\
0.7 \\
2.5\end{array}$ & $\begin{array}{l}\text { terbutryn } \\
\text { hydroxyatrazine } \\
\text { deethylatrazine } \\
\text { deisopropylatrazine } \\
\text { cyanazine } \\
\text { didealkylatrazine }\end{array}$ & $\begin{array}{l}2.5 \\
28 \\
30 \\
30 \\
40 \\
\text { no response }\end{array}$ \\
\hline
\end{tabular}

ating conditions were as follows: ionization voltage, $70 \mathrm{eV}$; ion source temperature, $250^{\circ} \mathrm{C}$; electron multiplier, 2200 $\mathrm{V}$; direct capillary interface at $280^{\circ} \mathrm{C}$, tuned daily with perfluorotributylamine; dwell time, $50 \mathrm{~ms}$. Separation of the herbicides was carried out using a fused-silica capillary column of methyl silicone (HP-1), a film thickness of 0.33 $\mu \mathrm{m}, 12 \mathrm{~m} \times 0.2 \mathrm{~mm}$ i.d., (Hewlett Packard). Helium was used as the carrier gas at a flow rate of $1 \mathrm{~mL} / \mathrm{min}$ and a head pressure of $35 \mathrm{kPa}$. The column temperature was held at $50^{\circ} \mathrm{C}$ for $1 \mathrm{~min}$ and then ramped at $6^{\circ} \mathrm{C} / \mathrm{min}$ to $250^{\circ} \mathrm{C}$ where it was held for $10 \mathrm{~min}$. Injector temperature was $280^{\circ} \mathrm{C}$. The filament and multiplier were not turned on until $5 \mathrm{~min}$ into the analysis. Quantification of the base peak of each compound was based on the response of the $m / z 188$ ion of the internal standard, phenanthrene- $d_{10}$. Confirmation of the compound was based on the presence of the molecular ion and two confirming ions with a retention time match of $\pm 0.2 \%$ relative to phenanthrene- $d_{10}$ (15).

\section{Results and Discussion}

The Spring Flush Phenomenon. Figure 2 shows the GIS display of the results of the herbicide survey by immunoassay. The ELISA data indicate that $55 \%$ of the basins exceeded the maximum contaminant level (MCL) for atrazine during the post planting sampling of 1989 . The ELISA cross reacts with ametryn, prometryn, prometon, propazine, simazine, and terbutryn, but not cyanazine and the degradation products of atrazine at the typical concentrations found in water samples (Table I). The GC/MS data indicate that cyanazine and deethylatrazine frequently were detected (Table II) with trace concentrations of simazine and propazine, but no detections of ametryn, prometon, prometryn, and terbutryn. In fact, atrazine was detected in $98 \%$ of the postplanting samples (Table II).

Because of the sensitivity of the microtiter plate ELISA, herbicide quantitation may be accomplished on as little as $100 \mu \mathrm{L}$ of sample with concentrations of $0.05 \mu \mathrm{g} / \mathrm{L}$ for atrazine. The detection limit of the test tube ELISA was slightly greater at $0.2 \mu \mathrm{g} / \mathrm{L}$. At this concentration, neither false positives nor false negatives were found. The correlation with GC/MS was good, with a correlation $\left(r^{2}\right)$ of 0.86 using a simple regression with a nonliner fit for 127 surface-water samples (Figure 3). The difference between the measured and predicted concentrations was less than $0.15 \mu \mathrm{g} / \mathrm{L}$ for $50 \%$ of the samples and less than $0.8 \mu \mathrm{g} / \mathrm{L}$ for $80 \%$ of the samples. Thus, ELISA is a viable tool for triazine surveys in the Midwest for samples such as surface water, groundwater, and precipitation.

The most striking feature of the reconnaissance data (Table II; Figure 2) was that large concentrations of herbicides were flushed from cropland and were transported through the surface-water system as pulses in response to late spring and early summer rainfall. The significance of the reconnaissance is that the pulse effect occurs at a 
Table II. Summary of Herbicide Concentrations Detected in Preplanting, Postplanting, and Harvest Samples

\begin{tabular}{|c|c|c|c|c|}
\hline \multirow[b]{2}{*}{ herbicide } & \multirow{2}{*}{\multicolumn{2}{|c|}{$\begin{array}{c}\text { detections } \\
(\%)\end{array}$}} & \multicolumn{2}{|c|}{ concns $(\mu \mathrm{g} / \mathrm{L})$} \\
\hline & & & median & maximum \\
\hline \multicolumn{5}{|c|}{ Preplanting } \\
\hline alachlor & 55 & 18 & $<0.05$ & 0.44 \\
\hline atrazine & 55 & 91 & 0.23 & 1.7 \\
\hline deethylatrazine & 55 & 54 & 0.05 & 0.39 \\
\hline deisopropylatrazine & 55 & 9 & $<0.05$ & 0.59 \\
\hline cyanazine & 55 & 5 & $<0.20$ & 0.52 \\
\hline metolachlor & 55 & 34 & $<0.05$ & 0.53 \\
\hline metribuzin & 55 & 2 & $<0.05$ & 0.16 \\
\hline propazine & 55 & 0 & $<0.05$ & $<0.05$ \\
\hline prometon & 55 & 0 & $<0.05$ & $<0.05$ \\
\hline simazine & 55 & 7 & $<0.05$ & 8.7 \\
\hline \multicolumn{5}{|c|}{ Postplanting } \\
\hline alachlor & 132 & 86 & 0.92 & 51 \\
\hline atrazine & 132 & 98 & 3.8 & 108 \\
\hline deethylatrazine & 132 & 86 & 0.28 & 4.4 \\
\hline deisopropylatrazine & 132 & 54 & 0.09 & 3.2 \\
\hline cyanazine & 132 & 63 & 0.97 & 61 \\
\hline metolachlor & 132 & 83 & 1.30 & 40 \\
\hline metribuzin & 132 & 53 & 0.14 & 7.6 \\
\hline propazine & 132 & 40 & $<0.05$ & 1.4 \\
\hline prometon & 132 & 23 & $<0.05$ & 0.93 \\
\hline simazine & 132 & 55 & 0.07 & 7.0 \\
\hline \multicolumn{5}{|c|}{ Harvest } \\
\hline alachlor & 145 & 12 & $<0.05$ & 0.5 \\
\hline atrazine & 145 & 76 & 0.23 & 3.1 \\
\hline deethylatrazine & 145 & 47 & $<0.05$ & 0.56 \\
\hline deisopropylatrazine & 145 & 0 & $<0.05$ & $<0.05$ \\
\hline cyanazine & 145 & 0 & $<0.20$ & $<0.20$ \\
\hline metolachlor & 145 & 44 & $<0.05$ & 3.4 \\
\hline metribuzin & 145 & 0 & $<0.05$ & $<0.05$ \\
\hline propazine & 145 & $<1$ & $<0.05$ & 0.08 \\
\hline prometon & 145 & 6 & $<0.05$ & 0.24 \\
\hline simazine & 145 & 3 & $<0.05$ & 0.21 \\
\hline
\end{tabular}

${ }^{a} N$, number of samples; concentrations were determined by $\mathrm{GC} / \mathrm{MS}$ with detection limits of $0.05 \mu \mathrm{g} / \mathrm{L}$ for all herbicides except cyanazine, which is $0.2 \mu \mathrm{g} / \mathrm{L}$. Not detected: ametryn, prometryn, and terbutryn.

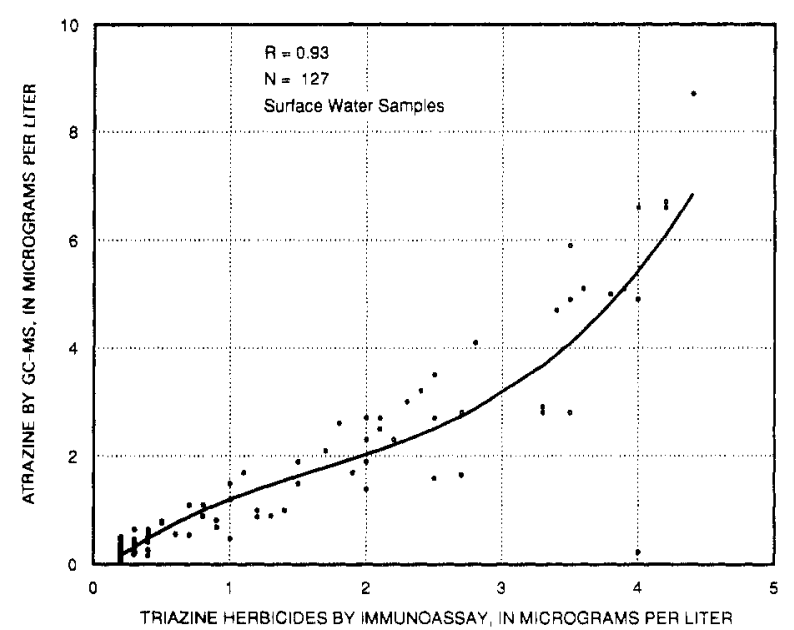

Figure 3. Plot of 127 surface-water samples from the midwestern United States showing ELISA concentration versus concentration by GC/MS. The equation of the regression line: [atrazine] (GC/MS, $\mu \mathrm{g} / \mathrm{L}$ ) $=0.21+2 I-0.73 I^{2}+0.15 I^{3}$, where $I$ is the triazine immunoassay result $(\mu \mathrm{g} / \mathrm{L})$.

regional scale throughout the midwestern United States and clearly appears to be linked to regional agricultural land use. Note the similarity of the distribution patterns of basins that exceeded MCLs (Figure 2) with the distribution pattern of percent corn and soybeans mapped by GIS (Figure 1B). The states of Illinois, Indiana, Iowa,
Ohio, and eastern Nebraska have the largest amounts of corn and soybeans grown and the most detections of atrazine that exceed the MCL $(3 \mu \mathrm{g} / \mathrm{L})$. It is important to realize that herbicides generally are applied to the fields in the spring for weed control. Fall application is minimal, and this is reflected in the small concentrations during the postharvest sampling. Only one basin exceeded the MCL for atrazine in the harvest sampling. None of the preplanting samples exceeded the atrazine MCL.

Figure 4 graphically summarizes the GC/MS data from the three sampling periods. Median concentrations of the four major herbicides (atrazine, alachlor, cyanazine, metolachlor) increased by 1 order of magnitude, or more, from the preplanting to the postplanting sampling periods and then decreased to near preplanting levels by the harvest sampling (Figure 4A). For example, the median concentration of atrazine during the postplanting period was 3.8 $\mu \mathrm{g} / \mathrm{L}$ compared with $0.2 \mu \mathrm{g} / \mathrm{L}$ during the preplanting and harvest periods (Table II). The total herbicide concentration, defined here as the sum of the concentrations of the 11 herbicides and 2 metabolites determined by GC/ MS, was calculated for each sample. The results (Figure $4 \mathrm{C}$ ) indicate that the median concentration of total herbicides in the 1989 postplanting was $8.7 \mu \mathrm{g} / \mathrm{L}$, or more than 20 times larger than the preplanting and harvest concentrations. Furthermore, resampling at one-third of the basins in 1990 showed similar concentration patterns (Figure 4C).

To determine whether there was any relation between the concentration of herbicides and the size of drainage basins, 132 stream samples from the postplanting sampling period (Table II) were divided equally into four size classes: $<807,807-2040,2040-6438$, and $>6438 \mathrm{~km}^{2}$. A nonparametric analysis of variance showed no significant differences in concentrations among the four classes for 8 of the 10 herbicides detected. Except for alachlor $(p=0.05)$ and cyanazine $(p=0.04)$, herbicide concentrations in the 33 smallest basins were not statistically different $(p=0.05)$ from the other three size classes. This was surprising because small streams react more quickly to storm runoff, which should result in larger concentrations.

Postplanting concentrations of several herbicides exceeded EPA MCLs for drinking water for a short, but undetermined, period of time following application. For example, samples from $52 \%$ of the sites exceeded the MCL for atrazine $(3.0 \mu \mathrm{g} / \mathrm{L})$. Samples from $32 \%$ of the sites exceeded the MCL for alachlor $(2.0 \mu \mathrm{g} / \mathrm{L})$, and $7 \% \mathrm{ex}$ ceeded the MCL for simazine $(1.0 \mu \mathrm{g} / \mathrm{L})$. The MCLs do not consider the cumulative or synergistic effects of exceeding the levels by more than one herbicide. In the postplanting sampling, $23 \%$ of the sites exceeded the MCLs for two herbicides, and $10 \%$ exceeded MCLs for three herbicides.

Storm Runoff. Figure 5 shows the storm-runoff data for three typical sites of the nine that were monitored for storm runoff in the heart of the herbicide-use area (Illinois, Iowa, Kansas, Nebraska, and Ohio). The ELISA data indicate that prior to herbicide application the concentration of triazines was less than $1.0 \mu \mathrm{g} / \mathrm{L}$. However, the concentration of herbicides increased sharply above the MCL for atrazine, with spikes of $30-40 \mu \mathrm{g} / \mathrm{L}$ during early May and June (postplanting period). GC/MS verification of the spikes showed that atrazine was the major triazine present, and alachlor and metolachlor were the major acetanilide herbicides found. Concentration spikes of 20 $\mu \mathrm{g} / \mathrm{L}$ occurred through late June as the late spring rains continued to wash herbicides from the fields. The other six sites had similar patterns. 

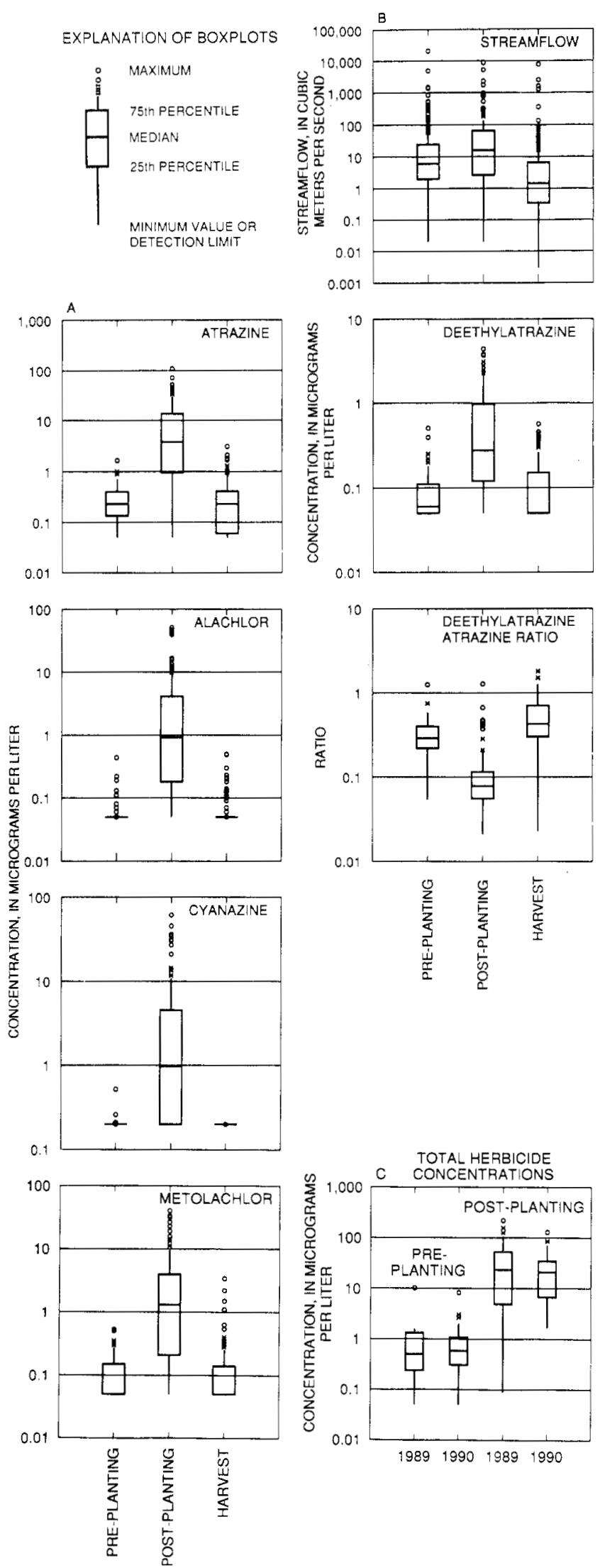

Figure 4. (A) Boxplots of herbicides detected using GC/MS during the three sampling periods of 1989 . (B) Boxplots of streamflow, deethylatrazine, and the deethylatrazine to atrazine ratio. (C) Boxplots of total herbicide concentrations comparing 1989 and 1990 results from preplanting and postplanting periods.

The concentration spikes correlated with stream discharge immediately following the herbicide application. Concentrations of herbicides were largest during the first
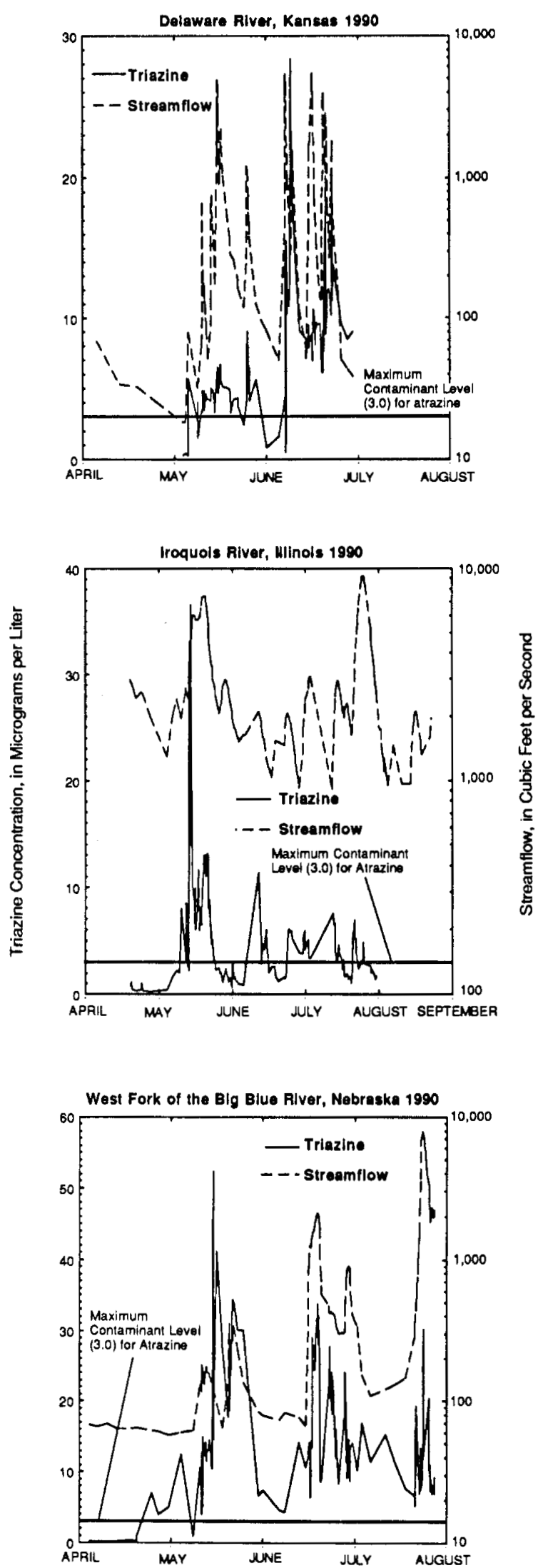

Flgure 5. Triazine concentratlons (expressed as atrazine) by ELISA versus streamflow for the Delaware River near Muscotah, KS, the Iroquois Rlver, near Chebanse, IL, and the West Fork of the Big Blue River, NE. Maximum contaminant level for atrazine is $3.0 \mu \mathrm{g} / \mathrm{L}$.

storm runoff after the majority of herbicides has been applied in the basins. Streamflow varied from 300 to $300000 \mathrm{~L}$ per second $\left(\sim 10-10000 \mathrm{ft}^{3} / \mathrm{s}\right)$. Thus, the major transport of herbicide occurred during these spring-runoff 
events. Base-flow conditions transport the least amount of herbicide from the basin. This result has been reported by others in the midcontinent $(8,9,22,23)$. The major importance of these automated storm-runoff samples is to show that the regional pulse of herbicide that was documented by the reconnaissance data in 1989-1990 during the postplanting is actually a series of pulses, which coincide with each storm event following application of herbicides and decrease gradually in concentration Nonetheless, the concentration of herbicides may easily exceed drinking-water regulations well into midsummer, where there are intense rain storms. It is important to realize that the quality of water in reservoirs may be affected by the practice of holding spring runoff as drinking water for the remainder of the year, which is a common practice in the Midwest.

Contamination of Alluvial Aquifers. Another important finding of the reconnaissance was the persistence of herbicides in surface water. One or more herbicides were detected at most sampling sites during all sampling periods (Table II). Measurable amounts of atrazine, the most frequently detected herbicide, occurred in $91 \%$ of the preplanting samples, $98 \%$ of the postplanting samples, and $76 \%$ of the harvest samples. Metolachlor, the second most frequently detected herbicide, occurred in $34 \%$ of the preplanting samples, $83 \%$ of the post planting samples, and in $44 \%$ of the harvest samples. Also, the atrazine metabolite, deethylatrazine, was found in many preplanting, postplanting, and harvest samples that contained atrazine. In fact, it was detected more frequently, but in smaller concentrations, than metolachlor.

The frequency of detection or apparent order of stability of the herbicides and their metabolites based on Figure 4 and Table $I I$ is atrazine $>$ deethylatrazine $>$ metolachlor $>$ alachlor $>$ deisopropylatrazine $>$ cyanazine. This stability relation may be interpretated from the number of detections of herbicides in both the preplanting and postharvest samples and in the range of the distribution during those two sampling periods (Figure 4A and B). Published decomposition rates support these findings (24). For example, atrazine has a reported half-life of 140 days; metolachlor, 90 days; cyanazine, 85 days; and alachlor, 50 days. Our work suggests that cyanazine is less stable than alachlor, which is different from reports in the soil literature (24). It is possible that cyanazine is less stable in the aquatic environment relative to the soil environment. Oxidation of the cyano group may be a cause of the instability. Cyanazine amide is an important degradation product of cyanazine (7) and would result from the oxidation of the cyano group. Half-lives were not available for deethylatrazine and deisopropylatrazine, but our findings are consistent with other work on atrazine metabolites in soil $(25,26)$.

The temporal trends in the number of detections of various herbicides are significant for several reasons. First, they indicate that some of the compounds persist from year to year in soil and water. Second, degradation products, such as deethylatrazine, are both persistent and mobile in water. Third, the data suggest that the ratio of deethylatrazine to atrazine (DAR), which has been suggested as an indicator of nonpoint-source pollution of groundwater (25), might be used also as a tracer of groundwater discharge into rivers.

Adams and Thurman (25) found that atrazine transport through the unsaturated zone gave DAR values greater than 1.0, whereas atrazine transported off the field by surface runoff had DAR values much less than 1.0. Furthermore, deisopropylatrazine was rapidly degraded in the
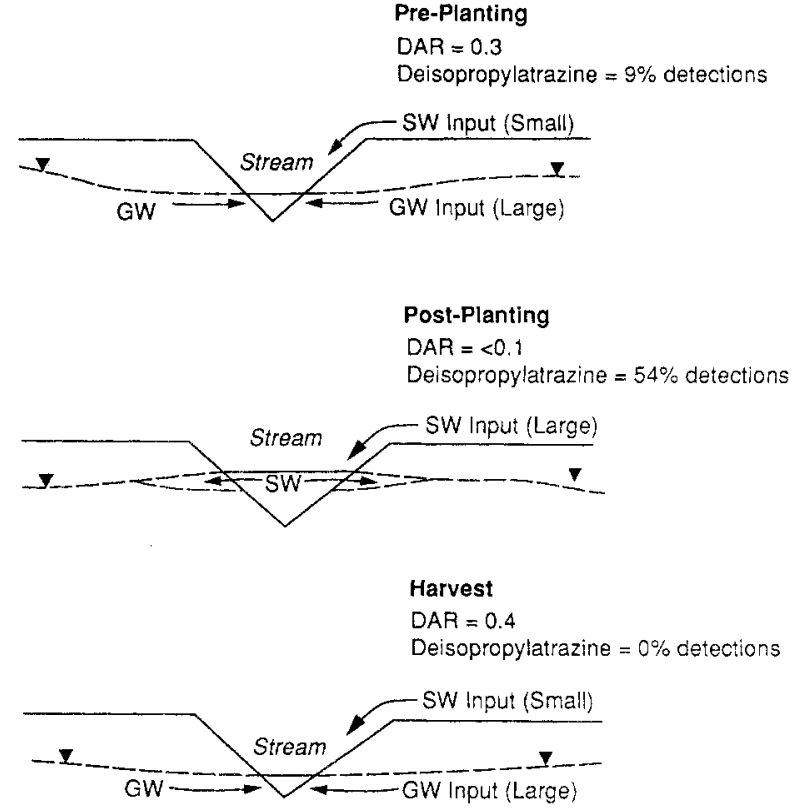

\section{EXPLANATION}

-Z GROUND-WATER TABLE
GW GROUND WATER
SW SURFACE WATER

Figure 6. Deethylatrazine to atrazine ratios (DAR) for groundwater and surface-water interactions.

unsaturated zone but was an important metabolite in surface runoff from the fields (26). Thus, the DAR may be indicative of groundwater recharge by atrazine-laden water. For example, the median DAR was 0.3 in the preplanting sampling, $<0.1$ in the postplanting sampling, and 0.4 in the harvest sampling (Figure $4 \mathrm{~B}$ and Figure 6). It is hypothesized that the large decrease in the DAR from 0.3 to $<0.1$ indicates that runoff of recently applied herbicides contains a low ratio of degradation product, in spite of the increased detections and greater concentrations of deethylatrazine (Figure 4B). The large increase in the DAR of $<0.1$ to 0.4 from the postplanting to the harvest sampling may reflect alluvial groundwater providing stream base flow and the flux of herbicides into surface water.

Figure 6 shows this hypothesis in diagrammatic form. The preplanting samples had a high DAR of 0.3 but also contained a few detections of deisopropylatrazine $(9 \%)$. These results suggest both a surface water and groundwater origin of herbicides at this sampling period, as do the discharge records. The surface component probably is related to recent spring melting of snow and ice. The postplanting samples collected during a period of runoff had a low DAR $(<0.1)$ and the greatest number of detections of deisopropylatrazine $(54 \%)$, which indicate that surface runoff is the major contributor of herbicides at this time. Finally, the postharvest sampling during a lowstreamflow period had the greatest DAR of 0.4 and no detections of deisopropylatrazine, which indicate that alluvial groundwater was likely the major source of herbicide at this time. The alluvial groundwater hypothesis is based on many decades of groundwater study that have shown that base flow may be used to calculate groundwater contributions to streamflow (e.g., refs 27 and 28). Our measurements of streamflow (Figure 4B) indicate that base-flow conditions predominated during the harvest sampling. 
Also it is hypothesized that surface water contaminated during the spring runoff may contribute significantly to alluvial groundwater contamination, a hypothesis first advocated by Squillace and Engberg (29). Mechanisms include a rapid increase in stream stage that occurs in spring when rivers are bank full. During this time, groundwater gradients may reverse, with flow moving into adjoining alluvial aquifers locally (Figure 6). Contaminated surface water also may enter alluvial aquifers by recharge from flood water and from upland runoff onto the alluvial plain. Later this water recharges the alluvial aquifer. Further, large alluvial plains are typically row-cropped in the Corn Belt, with these herbicides directly applied to the alluvial soils with the potential for leaching to the shallow groundwater in these systems. Current studies of atrazine degradation and transport rates are consistent with these multiple sources $(30,31)$.

\section{Conclusions}

Our results show that there is clearly a regional effect on water quality caused by runoff after spring planting. This work also indicates that more needs to be known about the duration of large herbicide concentrations (i.e., the number of pulses and their concentration maxima) during storm runoff and the possible implications of storing this water in reservoirs for long-term use. Furthermore, the number of samples, which were found where multiple MCLs were exceeded, reinforces the need for environmental health studies to examine the combined and synergistic effects of the major herbicides and their degradation products. Finally, future studies should include the persistent degradation products of herbicides, such as deethylatrazine and deisopropylatrazine, and their role as hydrologic tracers in surface-water and groundwater interactions.

Registry No. Alachlor, 15972-60-8; atrazine, 1912-24-9; deethylatrazine, 6190-65-4; deisopropylatrazine, 1007-28-9; cyanazine, 21725-46-2; metolachlor, 51218-45-2; metribuzin, 21087-64-9; propazine, 139-40-2; prometon, 1610-18-0; simazine, 122-34-9.

\section{Literature Cited}

(1) Humenik, F. J.; Smolen, M. D.; Dressing, S. A. Environ. Sci. Technol. 1987, 21, 737-742.

(2) Hileman, B. Chem. Eng. News, 1990, 68, 26-33.

(3) Gianessi, L. P.; Puffer, C. M. Use of selected pesticides for agricultural crop production in the United States, 19821985; NTIS: Springfield, VA, 1986; p 490.

(4) Sun, M. Science 1988, 239, 239.

(5) Richards, R. P.; Kramer, J. W.; Baker, D. B.; Krieger, K. A. Nature $1987,237,129-131$.

(6) Glotfelty, D. E.; Taylor, A. W.; Zoller, W. H. Science 1983, $219,843-845$

(7) Hallberg, G. R. Agric. Ecosyst. Environ. 1989, 26, 299-367.
(8) Leonard, R. A. In Environmental Chemistry of Herbicides; 1st ed.; Grover, R., Ed.; CRC: Boca Raton FL, 1988; Vol. 1, Chapter 3, pp 45-87.

(9) Wauchope, R. D. J. Environ. Qual. 1978, 7, 459-472.

(10) Glotfelty, D. E.; Taylor, A. W.; Isensee, A. R.; Jersey, J.; Glen, S. J. Environ. Qual. 1984, 13, 115-121.

(11) Pereira, W. E.; Rostad, C. E. Environ. Sci. Technol. 1990 24, 1400-1406.

(12) Kearney, P. C.; Muldoon, M. T.; Somich, C. J.; Ruth, J. M.; Voaden, D. J. J. Agric. Food Chem. 1988, 36, 1301-1306.

(13) Miltner, R. J.; Baker, D. B.; Speth, T. F.; Fronk, C. A. J.-Am. Water Works Assoc. 1989, 81, 43-52.

(14) deNoyelles, F.; Kettle, W. D.; Sinn, D. F. Ecology 1982, 63, 1285-1293.

(15) Butler, G. L.; Deason, T. R.; O'Kelley, J. C. Br. Phys. J. 1975, 10, 371-376.

(16) Kosinski, R. J.; Morris, G. M. J. Environ. Qual. 1984, 13, 75-81.

(17) Jones, T. W.; Winchell, L. J. Environ. Qual. 1984, 13, 243-247.

(18) Sun, M. Science 1986, 233, 1143.

(19) Averett, R. C.; Marzolf, G. R. Environ. Sci. Technol. 1989, $21,827$.

(20) Bushway, R. J.; Perkins, B.; Savage, S. A.; Lekousi, S. L. Bull. Environ. Contam. Toxico. 1988, 40, 647-654.

(21) Thurman, E. M.; Meyer, M.; Pomes, M.; Perry, C. A.; Schwab, A. P. Anal. Chem. 1990, 62, 2043-2048.

(22) Goolsby, D. A.; Thurman, E. M.; Clark, M. L.; Pomes, M L. In Immunoassays for Trace Chemical Analysis; Vanderlaan, M., Stanker, L. H., Watkins, B. E., Roberts, D. W. Eds; ACS Symposium Series 451; American Chemical Society: Washington, DC, 1990; pp 86-99.

(23) Thurman, E. M.; Goolsby, D. A.; Meyer, M. T.; Kolpin, D. W. Environ. Sci. Technol. 1991, 25, 1794-1796.

(24) Nash, R. B. In Environmental Chemistry of Herbicides; Grover, R., Ed.; CRC Press: Boca Raton, FL, 1988; pp 131-169.

(25) Adams, C. D.; Thurman, E. M. J. Environ. Qual. 1991, 20, 1400-1406.

(26) Mills, M. S. Field Dissipation of Encapsulated Herbicides: Geochemistry and Degradation. M.S. Thesis, Dept. of Geology, University of Kansas, Lawrence, KS, 1991.

(27) Linsley, R. K.; Kohler, M. A.; Paulhaus, J. L. H. Hydrology for Engineers, 2nd ed.; McGraw-Hill: New York, 1982; Vol. 1, Chapter 7, pp 204-231.

(28) Martinec, J. Water Resour. Res. 1975, 11, 496-498.

(29) Squillace, P. J.; Engberg, R. A. Water Resour. Invest. Rep. (U.S. Geol. Surv.) 1988, No. 88-4060.

(30) Wagenet, R. J.; Hutson, J. L. J. Environ. Qual. 1986, 15, 315-322.

(31) Jury, W. A.; Focht, D. D.; Farmer, W. J. J. Environ. Qual. $1987,16,422-428$.

Received for review May 1, 1992. Revised manuscript received August 6, 1992. Accepted August 12, 1992. The authors thank Gail Mallard of the Surface Water Toxics Program of the U.S. Geological Survey for supporting this research. The use of trade names in this article is for identification purposes only and does not imply endorsement by the U.S. Geological Survey. 